\title{
Creating legal rights for rivers: lessons from Australia, New Zealand, and India
}

\author{
Erin L. O'Donnell ${ }^{1}$ and Julia Talbot-Jones ${ }^{2}$
}

\begin{abstract}
As pressures on water resources increase, the demand for innovative institutional arrangements, which address the overuse of water, and underprovision of ecosystem health, is rising. One new and emerging approach is the use of legal personality to protect water systems in law through the granting of legal rights to rivers. This constitutes a significant development in the fields of environmental law and water resources management, yet little analysis is available of how the approach has been used and applied. We critically examine the new legal rights for rivers using three case studies from Australia, New Zealand, and India. We analyze how legal rights have been created in each case, and the complexity of enforcing these legal rights to protect the rivers. We conclude that legal personality could be a useful alternative approach for river management, provided that the new legal rights are given sufficient force and effect.
\end{abstract}

Key Words: Ganges; legal rights; river; Victorian Environmental Water Holder; Whanganui

\section{INTRODUCTION}

New sets of environmental pressures, unprecedented in their complexity, are confronting people around the world (OECD 2012, World Economic Forum 2015). The emerging problems involve interconnected ecological and social systems, and include ecological degradation, the under representation of indigenous peoples in decision making, declining resource availability, and climate change (Millennium Ecosystem Assessment 2005, Steffen et al. 2007, Haines-Young and Potschin 2010). The management of freshwater resources to maintain ecosystem health and wellbeing, as well as supporting local communities (see Bignall et al. 2016), is a particularly pressing and difficult problem (Arthington 2012, Hall et al. 2014, Horne et al. 2017a).

These problems require the development of innovative institutional arrangements that incentivize a change in the behavior of organizations and individuals (Head and Alford 2013). One such recent development has been the granting of legal personhood to nature. This involves recognizing nature - either as a whole, or a specific part, such as a river - as a legal person. In law, this means that nature has a basic set of legal rights that grants it certain rights, duties, and responsibilities (Naffine 2003). Although referred to as a legal "person," these legal rights are not the same as human rights, which include civil and political rights. Instead legal rights comprise three elements: legal standing (the right to sue and be sued in court), the right to enter and enforce legal contracts, and the right to own property (Naffine 2009, O’Donnell and Talbot-Jones 2017).

The concept of granting legal rights to nonhuman entities is not new (Salmond 1947, Stone 1972), but it has only recently begun to be implemented for nature. In 2008, Ecuador granted legal rights to nature in its constitution (Constitution of the Republic of Ecuador 2008, articles 71-74), explicitly recognizing the rights of nature, and empowering "all persons, communities, peoples and nations [to] call upon public agencies to enforce the rights of nature" (art 71). Similarly, in 2010, Bolivia created broad legal rights for nature when it passed "Ley de Derechos de la Madre Tierra" (the "Law of Mother Earth"). At the other end of the social scale, there are a growing number of local laws that create and protect the rights of nature. In the USA, local grassroots movements have worked to embed rights for nature within local constitutions, including the right for nature to exist and flourish (Burdon 2010, Troutman 2014).

More recently, the approach has been applied to specific natural features, namely rivers. In March 2017, three rivers, the Whanganui River in New Zealand, and the Ganges and Yamuna rivers in India, were given the legal status of persons, while in 2011 a hybrid form of the legal rights for nature concept was used to protect the rivers of the state of Victoria, Australia. These river ecosystems provide a range of services to human users, including basic water supply, hydropower, irrigation, navigation, and pollution control (Ross and Connell 2016). They are also of great significance to indigenous peoples and local communities (Alley 2010, Department of Environment, Land, Water and Planning 2016, Sachdeva 2016).

These cases offer the first examples of legal rights being applied to a specific, identifiable, bounded natural feature (a river and its catchment). The development has the potential to create new legal precedent in environmental law, and opens a fresh pathway for water resources management. In doing so it also presents a series of complex challenges for both law and management. For instance, a river's legal rights are only likely to be effective if they can be given force and effect. To possess a right implies that someone else has a commensurate duty to observe this right, in both law, and practice (Schlager and Ostrom 1992). In the context of water resources management, the efficacy of legal rights for rivers depends on both the river, and the other users of the resource, recognizing their joint rights, duties, and responsibilities.

Further, legal rights are only worth having if they can be enforced. To enforce legal rights for a river, several practical factors must be accounted for. First, an individual or organization must be appointed to act on a river's behalf, to uphold the rights of, and speak for nature (Croley 1998, Stone 2010). Second, capacity in the forms of time, money, and expertise may need to be made 
available so that the rights of the river can be upheld in court. And third, river representatives and funding sources are likely to need some form of independence from state and national governments, as well as sufficient real-world power to take action, particularly if such action is politically controversial (O'Donnell 2012).

Historically, these factors have been absent in cases where legal rights have been granted to nature and, as a result, legal rights for nature have been difficult to enforce (Whittemore 2011). For instance, in the examples of Ecuador and Bolivia, few cases have been successfully upheld and even when the rights have been recognized in court, local actors responsible for enforcement have lacked capacity to translate the legal decision into effective outcomes on the ground (Daly 2012).

In the context of water resources management the force and effect of legal rights is of particular importance. In this paper we use the three recent cases of the Victoria Environmental Water Holder in Australia, the Whanganui River in New Zealand, and with the Ganges and Yamuna rivers in India to examine how legal rights are being used as a tool to manage river health and the use of water resources. The three cases each use distinctive modes for creating legal rights for rivers and demonstrate different motivations for integrating legal rights into existing legislative frameworks. The discussion advances the environmental law debate, and shines new light on the development of water governance.

\section{WHY GIVE RIGHTS TO NATURE? A LEGAL BACKGROUND}

Protecting the environment through judicial process is one of the lasting legacies of the rapid expansion of environmental law that occurred through the 1960s and 1970s (Plater 1994, Gunningham 2009). Over this period, environmental law emerged as a distinct discipline and a range of legal tools were established to protect the environment from the impact of human activities (Sax 1971, Grinlinton 1990, Preston 2007, Fisher 2010). Since then, most environmental law has focused on either protecting particular special or iconic features, or by placing sustainable limits on development and use of resources (Doremus 2002, Stallworthy 2008, Fisher 2010, Godden and Peel 2010). However, these approaches have often obscured the particular interests of "nature" behind the effects of environmental degradation on human interests (Carlson 1998, Bertagna 2006, Sands 2012). For example, the public trust doctrine (Sax 1970) places emphasis on the public use of natural resources (Preston 2005) rather than the protection of nature itself. Addressing this obscurity has become one of the core challenges in environmental law.

The key question has become how to best represent the environment in court, and how to frame the legal challenges to deliver "judicial protection of nature for the sake of nature itself" (Daly 2012:63). Stone (1972) proposed a method to recognize the rights of nature in his seminal paper Should Trees Have Standing?, which showed how nature could be personified in law, so that it could seek legal redress on its own behalf. Stone combined a philosophical argument with key practical steps to enable the environment to become a legal subject. He identified three legal criteria that "go toward making a thing count jurally": (1) "that the thing can institute legal actions at its behest"; (2) "that in determining the granting of legal relief, the court must take injury to it into account"; and (3) "that relief must run to the benefit" of it (Stone 1972:458 [emphasis in the original]). The essence of these legal criteria is to create the possibility for nature to take action in court to protect its own interests: to give nature itself legal standing.

Although Stone's proposal has remained on the fringes of mainstream environmental law (Naffine 2012, Warnock 2012), it is premised on a concept widely accepted in law: that legal rights can be conferred on nonhuman entities. The creation of "legal fictions" is a long-standing mechanism to create legal personality for a range of nonhuman entities, including, most notably, forprofit corporations (Micklethwait and Wooldridge 2003, Truitt 2006, Farrar 2007). The advantage of this legal approach is that it creates a new, identifiable, legal entity (the legal person), which includes all the necessary legal rights (standing, contract, and property) for granting the nonhuman entity its own personality. Although there are limited examples of using the legal person in the environmental context, it has been used for many purposes throughout history, including businesses, not-for-profit charities, and religious organizations (Micklethwait and Wooldridge 2003), as well as Hindu deities. ${ }^{[1]}$

Not everyone thinks legal standing (the right to sue or be sued in court) for nature is a good idea, however. Several commentators have argued that legal standing for nature is an unnecessary complication of standing law, which is based on the notion that only directly affected individuals can bring actions in a court of law (Rolston 1993, Warnock 2012). Others have argued that the recent relaxation in environmental law of the definition of "harm" to humans has sufficiently lowered the hurdle to achieving legal standing (Sunstein 1992, Bertagna 2006, Preston 2006, Vanhala 2012). They argue that this relaxation makes it much easier for human plaintiffs to demonstrate the necessary harm, and seek redress for it, without requiring the creation of legal rights (Stone 2012).

However, the counter to this argument is that these other advances in environmental law actually provide two powerful reasons for extending legal rights to nature. First, from a philosophical perspective continuing to prosecute environmental cases on the basis of ever-more attenuated "harm" to humans relies on an increasingly convoluted and anthropocentric argument, which obscures the needs of nature (O'Riordan 1981, 1991). For example, there are many elements of nature that are not captured by existing anthropocentric paradigms such as natural capital or ecosystem services (see Salzmann 1997), and identifying environmental impacts outside of these conceptions is crucial for effective protection of the environment in law (Ruhl and Ruhl 2001). Although the advances in environmental law have enabled more environmental cases to be brought to court, the outcome has often been the conflation of the harm experienced by the natural object with the harm to human interests. This can ultimately devalue the natural environment, and continues to reinforce the anthropocentric position that nature only has value in terms of its benefit to humans (Bertagna 2006).

Second, the argument for the use of legal personality for protecting nature is one of efficiency and cost effectiveness. If the injuries to the environment (as opposed to the human users of, or participants in, that environment) are ignored, then a significant proportion of the total injuries are not accounted for. 
For example, the cost of poor water quality to users is calculated in terms of the costs of treatment necessary to improve the water quality to the required standard. However, this treatment may fail to address the broader issues associated with the river's ecosystem health and well-being. If the injuries to the river are not recognized in court, then they cannot be compensated for, which means that the true costs of environmental impacts may be underestimated. Further, without giving due consideration to the injuries imposed on the river, the damages to other potential plaintiffs may be insufficient to cover the costs of litigation. In some cases this may result in the litigation not proceeding.

These counter arguments have led to a number of legal models emerging over the past four decades, which have embraced and extended Stone's original concept. Many of these have been centered on the concept of guardianship or stewardship (Stone 2010) and have been motivated by indigenous worldviews (Morris and Ruru 2010) or eco-centrism (Cullinan 2010, Maloney and Burdon 2014). However, despite this growing interest in academic circles, the practical difficulty in creating enforceable legal rights for nature that improve environmental outcomes remains a limitation (Daly 2012). Part of the problem may lie in the complexity of granting rights to nature as a whole, the identification of guardians, and a failure to meet the practical steps of enforcement.

We now discuss the application of legal rights to nature in terms of its use for the Victoria Environmental Water Holder, Australia, the Whanganui River, New Zealand, and the Ganges and Yamuna rivers in India. In these cases, rather than granting rights to nature indiscriminately, legal rights are granted to a river system alone with specific guardians appointed to act on the rivers' behalf. The analysis focuses on how legal rights have been granted in each case, the strengths and weaknesses of the overall approach, and the likelihood of the legal rights being given force and effect and being able to deliver the desired water governance outcomes.

\section{LEGAL RIGHTS FOR RIVERS: THREE CASE STUDIES}

This study uses a case study approach. Case studies are traditionally defined using two dimensions: first, whether the cases are constructed based on theoretical concepts, or on empirical analysis; and second, whether the units of the case study are general, or specific (Ragin and Becker 1992). In this paper, the cases have been identified by the creation of the legal rights for nature (based on the specific legal evidence of these rights). The units of analysis are the legal entities that have been created in Australia, New Zealand, and India, the nature of the legal rights, the rivers to which they have been attached, and the geographical boundaries.

These cases have been chosen for three reasons. First, each case involves the creation of legal rights and legal personhood for a natural object rather than nature as a whole. Second, each case relates to water resources management, and the management of freshwater resources, in the face of environmental degradation caused by overextraction of water (Victoria), ongoing ownership contests (New Zealand), and pollution (India). Third, each example includes not only the creation of legal rights for nature, but some provision for the implementation and enforcement of these new legal rights. Together, the three cases offer insights into how legal rights for nature is being used in the water governance context.
The case studies are used to answer the question of how legal rights for nature can be created in a way that gives them sufficient force and effect. To undertake this analysis, a combination of archival material, legal documents (such as legislation and court rulings), policy documents and government reports, and media coverage has been used. These data are used to identify the background and legal context for the creation of the legal rights, the precise nature of the legal rights, the nature of the legal personhood (including purpose, powers, and limitations), and any broader institutional support provided (funding, organizational capacity, independence).

\section{Case study 1: The rivers of Victoria, Australia}

The state of Victoria is located in the southeast of Australia. Australia is a federated nation, but historically the states have retained responsibility for water resource management, and each state has its own water laws (Kildea and Williams 2010, Gardner et al. 2009). Victoria's water allocation framework was established under the Victorian Water Act 1989 and is designed around a water market that enables rights to take and use water to be traded (National Water Commission 2014).

The legal "umbrella" under which all water assigned for environmental use is held, is the Victorian Environmental Water Reserve (EWR; Department of Sustainability and Environment 2004, Foerster 2007). The EWR includes specific entitlements to water for the environment (usually but not always held in onstream dams), as well as water set aside by placing conditions on the water rights of other water users (such as the requirement to maintain a minimum instream flow). The purpose of the EWR is to provide and maintain the necessary river flows to support the health of rivers, wetlands, and estuaries throughout Victoria.

Until 2007, the Minister for Environment had "owned" the water entitlements for the environment. During the extreme Millennium Drought, it became apparent that this arrangement was placing environmental water management decisions under unnecessary political pressure (O’Donnell 2012). In 2010, ownership and decision-making responsibility for the water entitlements component of the EWR was granted to the newly established Victorian Environmental Water Holder (VEWH), a body corporate with the capacity and responsibility to hold and manage water rights for the purpose of maintaining and improving the health of the aquatic environment.

Following Stone's (1972) model, in law the VEWH was created as a legal person with the capacity to hold water rights, to decide how to use the available water each year, and was granted the power to buy and sell water on the water market (Victorian Environmental Water Holder 2013). The VEWH was created with legal rights, including the power to sue and be sued, the power to enter contracts, and the power to acquire, and hold and dispose of real and personal property on behalf of the environment (Water Act 1989, s33DB). Although the VEWH was created as a statutory corporation, it is not a corporation bound by Australia's Corporations Act 2001. Instead it is considered a public entity under Victoria's Public Administration Act 2004 and must therefore comply with Victoria's Financial Management Act 1994. The VEWH has three commissioners and a small staff, composed of state public service employees (Water Act 1989, s33DF, 33DM). Its funding comes from a levy placed on all water users in Victoria, which is designated for sustainable water resource management (the Environmental Contribution). 
The VEWH offers a working example of how an organization with legal personality has been established to hold and manage Victoria's environmental water rights (Water Act 1989, ss 33DC, 33DX, 33DY; see also, O'Donnell 2013; O'Donnell and Garrick 2017). Under the Water Act 1989, the VEWH is required to make a decision each year on how its water rights will be used. For instance, depending on the levels of flow within the system it can decide whether water is to be used instream, extracted for wetland use, or traded to other users (O'Donnell 2012). In doing so, the VEWH acts as a guardian for instream environmental flows, working with other environmental water holders and catchment management authorities to determine where, when, and how to use the water for the environment in the state of Victoria (O’Donnell 2013).

\section{Case study 2: Whanganui River, New Zealand}

The Whanganui River runs for $290 \mathrm{~km}$ from the centre of New Zealand's North Island, to the Tasman Sea on the North Island's lower west coast. As a navigable river, the Crown (New Zealand government) has formally owned the riverbed under legislation, while local authorities have been charged with management of the river and catchment. Since 1873, local Whanganui Māori have contested this legislative arrangement on Treaty of Waitangi ${ }^{[2]}$ grounds, with ongoing ownership challenges made through formal and informal channels (Waitangi Tribunal 1999). As part of settling these ongoing disputes, the Te Awa Tupua (Whanganui River Claims Settlement) Act 2017 (the Act), was passed in March 2017 as a Treaty of Waitangi settlement agreement after eight years of negotiation by Whanganui Iwi (tribe) and the Crown. The new Act grants legal personhood status to the Whanganui River and its catchment and creates a new governance framework for the river.

The new arrangement approximates the Whanganui Iwi worldview in law, acknowledging the river as a living whole that stretches from the mountains to the sea, including both its physical and metaphysical elements. The settlement Act recognizes the river and its catchment as a legal entity with all the rights, powers, duties, and liabilities of a legal person. This legal entity, Te Awa Tupua, has a hybrid form depending on the specific legal context in which the legal entity is operating. Rights to ownership of the riverbed are vested in Te Awa Tupua, and the new legal entity is granted the rights to sue and be sued, should it be necessary. Te Awa Tupua is to be represented by a guardian, Te Pou Tupua, who is required to act and speak to the benefit of the river's health and well-being. Te Pou Tupua will, in the spirit of the Treaty of Waitangi, New Zealand's founding document, consist of two persons, one appointed by the Crown, and the other by Whanganui Iwi, and are required to act as one.

Under legislation, a comprehensive institutional framework is to be developed to support the implementation of the new legal rights for the Whanganui River. Support will be offered to Te Pou Tupua through Te Karewao, an advisory group established by the Act. The Act also establishes a strategy group, Te Kopuka na Te Awa Tupua, which will develop and approve, review, and monitor the implementation of a strategy document, Te Heke Ngahuru, for Te Awa Tupua. The strategy group will consist of up to $17 \mathrm{key}$ stakeholder representatives, including iwi with interests in the Whanganui River, local and central government representatives, tourism, conservation, recreation, and wild game interests, and
Genesis Energy Limited, the operator of the Tongariro Power Scheme, which currently diverts $82 \%$ of the headwaters of the Whanganui River for hydropower.

The strategy group is a ready-made participatory group for collaborative planning required by the statutory process for managing the Whanganui River catchment. The framework intends to be inclusive rather than exclusive, creating a type of nested community governance within the broader legal framework (Tschirhart et al. 2016, Talbot-Jones 2017). Implementation of the Te Awa Tupua framework is supported through a series of payments to the river by the Crown, including a NZ\$30 million contestable fund, Te Korotete o Te Awa Tuриа, which can be used for the purposes of giving the rights of the river and its catchment force and effect.

\section{Case study 3: Ganges and Yamuna rivers, Uttarakhand, India}

The state of Uttarakhand is located on the northern border of India, and includes the headwaters of the Ganges River, as well as part of the Himalayas. On 20 March 2017, the High Court of Uttarakhand declared the following: "the Rivers Ganga and Yamuna, all their tributaries, streams, every natural water flowing with flow continuously or intermittently of these rivers, are declared as juristic/legal persons/living entities having the status of a legal person with all corresponding rights, duties and liabilities of a living person" (Indian Courts 2017:11). This decision came only days after the New Zealand parliament passed legislation that declared the Whanganui River catchment to be a legal person.

The court drew upon slightly different legal arguments to support the creation of legal rights for rivers. The creation of the Ganges and Yamuna rivers as legal persons was based on the court's assessment of the status of the rivers as "sacred and revered... central to the existence of half the Indian population" (Indian Courts 2017:11). The court also argued that the exposure of these "sacred" rivers to environmental degradation was causing the rivers to lose "their very existence [and that this] requires extraordinary measures to be taken to preserve and conserve Rivers Ganga and Yamuna" (Indian Courts 2017:4).

The court used the guardianship model to create the legal personality for the Ganges and Yamuna Rivers by establishing them as minors under the law. This arrangement ensures the legal status and rights of the rivers, whilst acknowledging that they cannot speak for themselves. Following Stone's model (Stone 2010), the court identified specific positions within the state government to act in loco parentis for the rivers, including the Director NAMAMI Gange, the Chief Secretary of the State of Uttarakhand, and the Advocate General of the State of Uttarakhand. Their responsibilities as set by the court are to be "the human face [and] to protect, conserve and preserve Rivers Ganga and Yamuna and their tributaries" (Indian Courts 2017:11-12).

However, on 7 July 2017, the Supreme Court of India agreed to hear an appeal against this ruling, and in doing so, halted the effect of the original case. The appeal was lodged by the state government of Uttarakhand, who argued that their responsibilities as guardians of the rivers were unclear because the rivers extend well beyond the borders of Uttarakhand (the Ganges River, in particular, extends through India into 
Table 1. Creating legal rights for rivers in Australia, New Zealand, and India.

\begin{tabular}{|c|c|c|c|}
\hline \multirow{2}{*}{$\begin{array}{l}\text { Legal and institutional } \\
\text { attributes }\end{array}$} & \multicolumn{3}{|c|}{ Jurisdiction } \\
\hline & Rivers of Victoria (Australia) & Whanganui River (New Zealand) & Ganges and Yamuna rivers (India) \\
\hline Legal standing & Yes & Yes & Yes \\
\hline Right to enter contracts & Yes & Yes & Yes \\
\hline Right to own property & Yes & Yes & Yes \\
\hline Other human rights & No & No & Yes \\
\hline Legal form & $\begin{array}{l}\text { Statutory body corporate (a hybrid of } \\
\text { the corporation and a public entity) }\end{array}$ & $\begin{array}{l}\text { Legal entity with the status of a legal } \\
\text { person, using a hybrid form (specific } \\
\text { interpretation of legal form is dependent } \\
\text { on legal context) }\end{array}$ & $\begin{array}{l}\text { Legal entity with the status of a legal } \\
\text { minor, with all corresponding rights, } \\
\text { duties, and liabilities of a living person }\end{array}$ \\
\hline $\begin{array}{l}\text { Explicit creation of legal } \\
\text { rights for nature }\end{array}$ & No & $\begin{array}{l}\text { Partial: a combination of legal rights for } \\
\text { nature and a recognition of Indigenous } \\
\text { worldviews }\end{array}$ & Yes \\
\hline Natural elements protected & $\begin{array}{l}\text { Water rights that can be used to provide } \\
\text { environmental flows for rivers and } \\
\text { wetlands at particular locations in the } \\
\text { state of Victoria }\end{array}$ & $\begin{array}{l}\text { Whanganui River bed from the } \\
\text { mountains to the sea, and its catchment } \\
\text { (does not apply to existing rights to } \\
\text { water and land held privately) }\end{array}$ & $\begin{array}{l}\text { Ganges and Yamuna rivers (extent and } \\
\text { specificity of protection is unclear) }\end{array}$ \\
\hline Aims of creation & $\begin{array}{l}\text { Political and economic: to create a single } \\
\text { voice for decision making about use and } \\
\text { trade of environmental water in Victoria }\end{array}$ & $\begin{array}{l}\text { Treaty settlement: settlement under the } \\
\text { Treaty of Waitangi to approximate } \\
\text { Māori te ao values in legislation }\end{array}$ & $\begin{array}{l}\text { Environmental and religious: protection } \\
\text { of sacred and ecologically valuable } \\
\text { objects from environmental degradation }\end{array}$ \\
\hline Method of creation & Legislation & Legislation & Judicial decision \\
\hline Legal representative & $\begin{array}{l}\text { VEWH (body corporate), with three } \\
\text { appointed commissioners }\end{array}$ & Appointed guardians & Court-appointed guardians \\
\hline $\begin{array}{l}\text { Independence from } \\
\text { government }\end{array}$ & $\begin{array}{l}\text { Yes (for decisions about how } \\
\text { environmental water is used) }\end{array}$ & Yes & Uncertain \\
\hline Financial support & Yes (levy) & Yes (dedicated funding) & No \\
\hline
\end{tabular}

Bangladesh). As a result, the current legal status of the rivers is in limbo, pending the outcome of this appeal (O'Donnell 2017a).

\section{COMPARATIVE ANALYSIS: LESSONS FROM THE CASE STUDIES}

The case studies demonstrate three distinct ways of creating legal personhood and legal rights for nature in the context of water resources management (Table 1). The new approach is shown to be adaptable and flexible, with each case using a different combination of legal form, mode of creation, specific legal rights, aims, and institutional arrangements in order to achieve the same broad outcome of granting the rivers legal rights.

The following discussion focuses on two important elements for giving rights for rivers force and effect: the creation of specific legal rights and their enforcement.

\section{Creating legal rights for nature}

Each of the three cases create formal legal rights for nature and link these rights to specific natural objects: the environmental water rights in the rivers of Victoria, the Whanganui River in New Zealand, and the Ganges and Yamuna rivers in India. In each case, legal rights have been used as a mechanism to address a complex set of pressures that required an innovative approach to water governance that stepped outside the standard approaches taken in environmental law and water resources management. Yet, the analysis also shows that despite this commonality, each case has several points of differentiation. Comparing across cases shows that different modes were used for implementing the legal rights, that they were implemented for different reasons, and different legal tools were used to give effect to the legal rights.

In Australia, the creation of a legal person was not intended to revolutionize water resources management, but rather to provide a much needed circuit-breaker in the political arguments about how much water should be recovered for the environment (Department of Sustainability and Environment 2009). The VEWH, in particular, was created to shift the conversation from recovery of environmental flows to management, and show that the environment could use its large volumes of water rights efficiently and effectively. The legal form used for the VEWH also provided greater legal protection of those water rights in times of scarcity, without undermining the existing water allocation framework in Victoria (O’Donnell 2012).

The concept of legal rights for the environment was incorporated into the water market by identifying the VEWH as an entity with legal personhood (a statutory corporation), and granting it the right to hold environmental water entitlements. Historically, one of the key challenges in the design of water markets has been the adequate protection of environmental flows. Traditionally, the approach has been to design water markets with a cap, which takes into account ecological health; however, setting the cap at the appropriate level has proven difficult and is not always sufficiently flexible (Horne et al. 2011, 2017b). An alternative has been to allow private parties to purchase water rights on behalf of the environment and participate in the market through the trade and exchange of rights (Malloch 2005, Garrick et al. 2009). The VEWH is an extension of this particular model, providing for the incorporation of environmental values and market participation using a hybrid corporate form that captures the specific characteristics of Stone's model (Garrick and O'Donnell 2015).

Similarly, the creation of Te Awa Tupua in New Zealand was a pragmatic way to alter ownership arrangements for the bed of the Whanganui River through legislation, without causing too much disruption to existing management structures, whilst simultaneously settling Whanganui Iwi's long-standing Treaty of 
Waitangi claims (Talbot-Jones 2017). In the case of the Whanganui River, identifying the river as a legal person allowed existing worldviews to be bridged through the creation of an alternative institutional arrangement for governing the river that was acceptable to Iwi and politically acceptable to the Crown. The outcome was the identification of the river and its catchment as a legal entity, for which the interpretation of legal form is dependent on the legal context. For instance, section 17 of the Act states that under the Resource Management Act, New Zealand's leading piece of environmental legislation, Te Awa Tupua is to be recognized as a public authority, but will also be recognized as a body corporate under section 188 (for the purpose of applying to be a heritage protection authority). This gives the arrangement flexibility, and ensures the new legal entity can be more easily incorporated into the 26 pieces of affected nationallevel legislation.

In contrast, in India, the creation of legal rights for rivers and other natural objects in Uttarakhand was undertaken swiftly through court rulings. Although the court drew on recognized legal doctrines to support their decision, the case represents a dramatic shift in the legal frameworks for environmental protection in India, and is currently under appeal (O'Donnell 2017a). Unlike the Australian and New Zealand cases, the granting of legal standing to the Ganges and Yamuna rivers was not explicitly designed to be integrated with existing legislative frameworks, and is instead meant to provide a substantive shift in the way that the rivers are managed and protected in law. The court decision has created specific legal rights for the rivers, but has also blurred the important distinction between legal rights and human rights by conflating the legal person with the living person (O’Donnell 2017a).

This comparison suggests that legal rights for nature can be implemented using existing legal tools and that creating legal rights for rivers can be a flexible response to context-specific issues. This combination of workability and flexibility has not been recognized until now, and these features of the legal rights for nature approach mean that it could well be far more widely applicable than previously thought.

\section{Enforcing legal rights for nature}

Although the three cases display similarities in the form of legal rights created, they differ in the likelihood of their future enforceability. In the introduction several necessary characteristics were identified for ensuring that legal rights are given force and effect. These included the nature of the legal entity that holds the legal rights, independence from government, and the provision of funding and organizational support to uphold the rights. Each of the cases examined differed in each of these categories, potentially affecting the likelihood that the rights will be upheld and enforced.

In Victoria, the VEWH is a statutory corporation with the right, duty, and responsibility to speak and make decisions on behalf of the rivers and water-dependent ecosystems in Victoria. The VEWH is one of many similar statutory corporations with various roles in water resource management in Victoria, and the use of a familiar legal form in the case of the VEWH provided it with increased legitimacy and power in decision making (O'Donnell 2017b). In addition, this legal form provided the VEWH with distinct organizational identity, and the legislation has insulated it from political interference (O’Donnell 2012). In practice, the VEWH has retained bipartisan political support in Victoria, and has established itself as an independent decision maker for Victoria's rivers. The VEWH participates in the water market as both a buyer and a seller of water rights, and other actors operating in the market respect its legal rights to water.

Likewise, the Te Awa Tupua (Whanganui River Claims Settlement) Act establishes a new institutional arrangement, which fully incorporates the concept of legal personhood into existing New Zealand legal frameworks. The Te Awa Tupua Act sits at the national level, providing the legislation with power and authority, while simultaneously providing for decentralized decision making by creating a series of actors and rules to operationalize legal personhood at the local level and encourage multistakeholder and community participation (Talbot-Jones 2017). Statutory independence for the guardians is granted by the legislation, and financial support is assured through the identification of a NZ\$30million contestable fund, which can be used "to support the health and well-being of Te Awa Tupua" (s57.3). These characteristics suggest that the framework will allow for the river's rights to be given force and effect, assuming that other actors recognize the new sets of rights. It should be noted, however, that a remaining source of uncertainty is the treatment of water in the new setting. The legislation specifically precludes the creation of rights to water, and, as a result, the longterm role of Te Pou Tupua in water use decisions remains unclear at this early stage.

Both the Victorian and New Zealand cases contrast strongly with the legal rights for rivers created in India in several ways. First, the Ganges and Yamuna rivers are transboundary rivers that stretch across several states in India, as well as into neighboring Bangladesh. Recognizing the rivers as legal persons in the state of Uttarakand will not necessarily translate into rights that can be enforced across state and national borders. This is one of the key arguments put forward by the State Government of Uttarakhand in their appeal to the Supreme Court (O'Donnell 2017a).

Second, although the court has designated responsibility of enforcing these rights to specific individuals, the individuals all hold roles in the state government bureaucracy, potentially creating conflicts of interest. Third, these individuals have not been given additional funding to support their new responsibilities to the rivers. Finally, by vesting the responsibility in individual bureaucrats, the court also failed to give the rivers clear organizational boundaries (O'Donnell and Garrick 2017). In practice, this may limit the ability of the appointed guardians to act cohesively on behalf of the rivers, and exposes them to the risk of interference (formal or informal) from the state government. The recent appeal of the decision of the High Court of Uttarakhand by the state government indicates the reluctance of the state government to take on any new responsibilities established by the court.

\section{CONCLUSION}

In analyzing the case studies from Australia, New Zealand, and India we have reached three key conclusions about the granting of legal rights to rivers. First, legal rights for nature can be created within a range of legal and institutional settings to address a number of complex socio-environmental and economic problems. 
One of the most unexpected findings from this analysis was that the legal rights for rivers approach can be used to address problems motivated by economic, cultural, or environmental factors as in the case of Australia, New Zealand, and India, respectively. In addition, it can be used to complement legislative frameworks ranging from state ownership models through to water markets, highlighting the broad potential applicability of the approach.

Second, it is possible to create legal rights through both judicial and legislative channels. This makes legal rights a flexible water governance tool with its own set of opportunities and limitations. Achieving change through legislative channels, as occurred in Australia and New Zealand, can be slow, but effective. In contrast, the Indian case showed that legal rights for rivers can be granted rapidly through the judicial process, but can be equally rapidly undermined by further rulings. Although the High Court of Uttarakhand created some very broad legal rights for the Ganges and Yamuna rivers, the rulings lack the institutional depth of the legislated examples in Australia and New Zealand. In India, the absence of broader government engagement raises questions about the Ganges and Yamuna rivers' guardians' likely ability to act, given the absence of financial support, institutional capacity, and statutory independence. The recent appeal to the Supreme Court of India is demonstrative of the type of uncertainty that could be created by granting legal rights to rivers through the judicial system.

Third, this analysis suggests that granting rights to nature no longer sits on the fringes of environmental law. These three cases represent a development in environmental law and demonstrate a new way in which nature can be granted legal standing. Where nature has been given legal rights previously, namely in Ecuador and Bolivia, a distinct limitation of the approach has been the inability to give the rights force and effect. This analysis shows that the approaches taken in Australia and New Zealand could overcome some of the challenges experienced in the earlier cases and deliver outcomes to the benefit of the environment and society.

The cases evaluated here shine light on how legal rights for rivers can be used to address a range of issues commonly observed in water resources management. As pressures on freshwater systems continue to increase, understanding the opportunities and limitations provided by this new legal approach will allow decision makers to make more informed choices when considering ways of addressing their context-specific socio-environmental and economic pressures.

${ }^{[1]}$ In Vidya Varuthi Thirthia Swamigal v. Baluswami Ayyar, [1922] AIR. [online] URL: https://indiankanoon.org/doc/242776/

${ }^{[2]}$ The Treaty of Waitangi was signed in New Zealand in 1840 by representatives of the British Crown and over 500 Māori chiefs. Widely viewed as New Zealand's founding document, conflicting English and Māori versions have led to ongoing disagreements over governance and ownership of land and resources in New Zealand (Stokes 1992). In cases where the Crown has been found to have contravened the principles of the Treaty since 1840 , settlement agreements, such as that which resulted in the Te Awa Tupua (Whanganui River Claims Settlement) Act 2017, have been entered into (Wheen and Hayward 2012).
Responses to this article can be read online at: http://www.ecologyandsociety.org/issues/responses. $\mathrm{php} / 9854$

\section{Acknowledgments:}

An early version of this paper was presented at the Australian Earth Laws Alliance conference in Brisbane, in 2016. We are grateful for all comments and suggestions received at this conference, which helped to shape the final paper.

\section{LITERATURE CITED}

Alley, K. D. 2010. The Goddess Ganga: her power, mythos, and worldly challenges. Pages 33-48 in P. Monaghan, editor. Goddesses in world culture. Praeger, Santa Barbara, California, USA.

Arthington, A. H. 2012. Environmental flows: saving rivers in the Third Millennium. University of California Press, Berkeley, California, USA. http://dx.doi.org/10.1525/california/9780520273696.001.0001

Bertagna, B. R. 2006. "Standing up" for the environment: the ability of plaintiffs to establish legal standing to redress injuries caused by global warming. Brigham Young University Law Review 2006:415-471.

Bignall, S., S. Hemming, and D. Rigney. 2016. Three ecosophies for the Anthropocene: environmental governance, continental posthumanism and indigenous expressivism. Deleuze Studies 10 (4):455-478. http://dx.doi.org/10.3366/dls.2016.0239

Burdon, P. 2010. The Rights of Nature: Reconsidered. Australian Humanities Review 49:69-89.

Carlson, A. E. 1998. Standing for the environment. UCLA Law Review 45:931-1004.

Croley, S. P. 1998. Theories of regulation: incorporating the administrative process. Columbia Law Review 98(1):1-168. http:// dx.doi.org/10.2307/1123396

Cullinan, C. 2010. A history of wild law. Pages 24-38 in P. Burdon, editor. Wild law: the philosophy of Earth jurisprudence. Wakefield, Adelaide, Australia.

Daly, E. 2012. The Ecuadorian exemplar: the first ever vindications of constitutional rights of nature. Review of European, Comparative \& International Environmental Law 21 (1):63-66. http://dx.doi.org/10.1111/j.1467-9388.2012.00744.x

Department of Environment, Land, Water and Planning (Vic). 2016. Water for Victoria: water plan. State Government Victoria, Melbourne, Australia.

Department of Sustainability and Environment (Vic). 2004. Victorian Government white paper: securing our water future together. State of Victoria, Melbourne, Australia.

Department of Sustainability and Environment (Vic). 2009. Northern region sustainable water strategy. State of Victoria, Melbourne, Australia.

Doremus, H. 2002. Biodiversity and the challenge of saving the ordinary. Idaho Law Review 38:325-354. 
Farrar, J. H. 2007. Salmond and corporate theory. Victoria University of Wellington Law Review 38:925-934.

Fisher, D. E. 2010. Australian environmental law: norms, principles and rules. Thomson Reuters, Sydney, Australia.

Foerster, A. 2007. Victoria's new environmental water reserve: what's in a name? Australasian Journal of Natural Resources Law and Policy 11(2):145.

Gardner, A., R. Bartlett, and J. Gray, J. 2009. Water resources law. Lexisnexis Butterworths, Chatswood, Australia.

Garrick, D., and E. O'Donnell. 2015. Exploring private roles in environmental watering in Australia and the U.S. Pages 203-232 in J. Bennett, editor. Protecting the environment, privately. World Scientific, Singapore. http://dx.doi.org/10.1142/97898146754440010

Garrick, D., M. A. Siebentritt, B. Aylward, C. J. Bauer, and A. Purkey. 2009. Water markets and freshwater ecosystem services: policy reform and implementation in the Columbia and MurrayDarling Basins. Ecological Economics 69:366-379. http://dx.doi. org/10.1016/j.ecolecon.2009.08.004

Godden, L., and J. Peel. 2010. Environmental law: scientific, policy and regulatory dimensions. Oxford University Press, South Melbourne, Australia.

Grinlinton, D. 1990. The "environmental era" and the emergence of "environmental law" in Australia - a survey of environmental legislation and litigation 1967-1987. Environmental and Planning Law Journal 7:74.

Gunningham, N. 2009. Environmental law, regulation and governance: shifting architectures. Journal of Environmental Law 21(2):179-212. http://dx.doi.org/10.1093/jel/eqp011

Haines-Young, R., and M. Potschin. 2010. The links between biodiversity, ecosystem services and human well-being. Pages 110-139 in D. G. Raffaelli and C. L. J. Frid, editors. Ecosystem ecology: anew synthesis. Cambridge University Press, Cambridge, UK. http://dx.doi.org/10.1017/CBO9780511750458.007

Hall, J. W., D. Grey, D. Garrick, F. Fung, C. Brown, S. J. Dadson, and C. W. Sadoff. 2014. Coping with the curse of freshwater variability. Science 346:429-430. http://dx.doi.org/10.1126/ science. 1257890

Head, B. W., and J. Alford. 2013. Wicked problems: implications for public policy and management. Administration \& Society 47 (6):711-739. http://dx.doi.org/10.1177/0095399713481601

Horne, A., J. Freebairn, and E. O'Donnell. 2011. Establishment of environmental water in the Murray-Darling Basin: an analysis of two key policy initiatives. Australian Journal of Water Resources 15(1):7-19. http://dx.doi.org/10.1080/13241583.2011.11465386

Horne, A., E. O’Donnell, and R. Tharme. 2017b. Mechanisms for allocating environmental water. Pages 361-398 in A. Horne, M. Stewardson, A. Webb, M. Acreman, and B. Richter, editors. Water for the environment: from policy and science to implementation and management. Academic, Cambridge, Massachusetts, USA.

Horne, A., A. Webb, M. Stewardson, B. Richter, and M. Acreman, editors. 2017a. Water for the environment: from policy and science to implementation and management. Academic, Cambridge, Massachusetts, USA.
Indian Courts. 2017. Ganges and Yamuna Case, Mohd. Salim v State of Uttarakhand \& others, WPPIL 126/2014, Uttarakhand High Court at Nainital, 2017. Indian Courts, Judgments - High Court of Uttarakhand at Nainital, India. [online] URL: http:// lobis.nic.in/ddir/uhc/RS/orders/22-03-2017/RS20032017WPPIL1262014. pdf

Kildea, P., and G. Williams. 2010. The constitution and the management of water in Australia's rivers. Sydney Law Review 32:595-616.

Malloch, S. 2005. Liquid assets: protecting and restoring the west's rivers and wetlands through environmental water transactions. Trout Unlimited, Arlington, Virginia, USA.

Maloney, M., and P. Burdon, editors. 2014. Wild law - in practice. Routledge, Oxon, UK.

Micklethwait, J., and A. Wooldridge. 2003. The company: a short history of a revolutionary idea. The Modern Library, New York, New York, USA.

Millennium Ecosystem Assessment. 2005. Ecosystems and human well-being: synthesis. Island, Washington, D.C., USA.

Morris, J. D., and J. Ruru. 2010. Giving voice to rivers: legal personality as a vehicle for recognising indigenous peoples' relationships to water? Australian Indigenous Law Review 14 (2):49-62.

Naffine, N. 2003. Who are law's persons? From Cheshire Cats to responsible subjects. Modern Law Review 66(3):346-367. http:// dx.doi.org/10.1111/1468-2230.6603002

Naffine, N. 2009. Law's meaning of life: philosophy, religion, Darwin and the legal person. Hart, Oxford, UK.

Naffine, N. 2012. Legal personality and the natural world: on the persistence of the human measure of value. Journal of Human Rights and the Environment 3(Special Issue):68-83. http://dx.doi. org/10.4337/jhre.2012.02.04

National Water Commission. 2014. Australian water markets: trends and drivers 2007-08 to 2012-13. National Water Commission, Canberra, Australia.

O’Donnell, E. 2012. Institutional reform in environmental water management: the new Victorian environmental water holder. Journal of Water Law 22:73-84.

O'Donnell, E. 2013. Australia's environmental water holders: Who is managing our environmental water? Australian Environment Review 28(3):508-513.

O'Donnell, E. 2017a. At the intersection of the sacred and the legal: rights for nature in Uttarakhand, India. Journal of Environmental Law. http://dx.doi.org/10.1093/jel/eqx026

O'Donnell, E. 2017b. Constructing the aquatic environment as a legal subject: legal rights, market participation, and the power of narrative. Dissertation. Melbourne Law School, University of Melbourne, Melbourne, Australia. [online] URL: http://hdl. handle.net/11343/191749

O'Donnell, E., and D. Garrick. 2017. Environmental water organizations and institutional settings. Pages 421-452 in A. Horne, A. Webb, M. Stewardson, B. Richter, and M. Acreman, 
editors. Water for the environment: from policy and science to implementation and management. Academic, Cambridge, Massachusetts, USA. http://dx.doi.org/10.1016/B978-0-12-803907-6.00019$\underline{X}$

O’Donnell, E., and J. Talbot-Jones. 2017. Legal rights for rivers: what does this actually mean? Australian Environment Review 32 (6):159-162.

O'Riordan, T. 1981. Environmentalism. Pion, London, UK.

O'Riordan, T. 1991. The new environmentalism and sustainable development. Science of the Total Environment 108:5-15. http:// dx.doi.org/10.1016/0048-9697(91)90230-C

Organisation for Economic Co-operation and Development (OECD). 2012. OECD Environmental Outlook to 2050. OECD Publishing, Paris, France. [online] URL: http://dx.doi. org/10.1787/9789264122246-en

Plater, Z. J. B. 1994. From the beginning, a fundamental shift of paradigms: a theory and short history of environmental law. Loyola of Los Angeles Law Revew 27:981-1008.

Preston, B. J. 2005. The role of the judiciary in promoting sustainable development: the experience of Asia and the Pacific. Asia Pacific Journal of Environmental Law 9:109-212.

Preston, B. J. 2006. The role of public interest environmental litigation. Environmental and Planning Law Journal 23:337-350.

Preston, B. J. 2007. Environmental law 1927-2007: retrospect and prospect. Australian Law Journal 81:616-637.

Ragin, C. C., and H. S. Becker. 1992. What is a case?: exploring the foundations of social inquiry. Cambridge University Press, Cambridge, UK.

Rolston III, H. 1993. Rights and responsibilities on the home planet. Yale Journal of International Law 18:251. [online] URL: http://digitalcommons.law.yale.edu/yjil/vol18/iss1/8

Ross, A., and D. Connell. 2016. The evolution and performance of river basin management in the Murray-Darling Basin. Ecology and Society 21(3):29. http://dx.doi.org/10.5751/ES-08664-210329

Ruhl, J. B., and R. J. Gregg. 2001. Integrating ecosystem services into environmental law: a case study of wetlands mitigation banking. Stanford Environmental Law Journal 20:365-392.

Sachdeva, S. 2016. The influence of sacred beliefs in environmental risk perception and attitudes. Environment \& Behavior 49(5):583-600. http://dx.doi.org/10.1177/0013916516649413

Salmond, J. 1947. Jurisprudence. Sweet \& Maxwell, London, UK.

Salzmann J. 1997. Valuing ecosystem services. Ecology Law Quarterly 24:887-904.

Sands, P. 2012. On being 40: a celebration of 'should trees have standing?' Journal of Human Rights and the Environment 3(Special Issue):2-3. http://dx.doi.org/10.4337/jhre.2012.02.01

Sax, J. L. 1970. The public trust doctrine in natural resource law: effective judicial intervention. Michigan Law Review 68 (3):471-566. http://dx.doi.org/10.2307/1287556

Sax, J. L. 1971. Defending the environment: a handbook for citizen action. Vintage Books, New York, New York, USA.
Schlager, E., and E. Ostrom. 1992. Property-rights regimes and natural resources: a conceptual analysis. Land Economics 68 (3):249-262. http://dx.doi.org/10.2307/3146375

Stallworthy, M. 2008. Understanding environmental law. Sweet \& Maxwell, London, UK.

Steffen, W., P. J. Crutzen, and J. R. McNeill. 2007. The Anthropocene: are humans now overwhelming the great forces of nature? Ambio 36:614-621. http://dx.doi.org/10.1579/0044-7447 (2007)36[614:TAAHNO]2.0.CO;2

Stokes, E. 1992. The Treaty of Waitangi and the Waitangi Tribunal: Māori claims in New Zealand. Applied Geography 12 (2):176-191. http://dx.doi.org/10.1016/0143-6228(92)90006-9

Stone, C. D. 1972. Should trees have standing? Towards legal rights for natural objects. Southern California Law Review 45:450-501.

Stone, C. D. 2010. Should trees have standing? Law, morality and the environment. Oxford University Press, New York, New York, USA.

Stone, C. D. 2012. Response to commentators. Journal of Human Rights and the Environment 3(Special Issue):100-120. http://dx. doi.org/10.4337/jhre.2012.02.06

Sunstein, C. R. 1992. What's standing after Lujan? Of citizen suits, "injuries," and article III. Michigan Law Review 91 (2):163-236. http://dx.doi.org/10.2307/1289685

Talbot-Jones, J. 2017. The institutional economics of granting a river legal standing. Dissertation. Crawford School of Public Policy, Australian National University, Canberra, Australia.

Troutman, M. 2014. Pennsylvania ecosystem fights corporation for rights in landmark fracking lawsuit. Public Herald, 10 December. [online] URL: http://www.publicherald.org/archives/19582/ invisible hand/

Truitt, W. B. 2006. The corporation. Greenwood, Westport, Connecticut, USA.

Tschirhart, C., J. Mistry, A. Berardi, E. Bignante, M. Simpson, L. Haynes, R. Benjamin, G. Albert, R. Xavier, B. Robertson, O. Davis, C. Verwer, G. De Ville, and D. Jafferally. 2016. Learning from one another: evaluating the impact of horizontal knowledge exchange for environmental management and governance. Ecology and Society 21(2):41. http://dx.doi.org/10.5751/ ES-08495-210241

Vanhala, L. 2012. Legal opportunity structures and the paradox of legal mobilization by the environmental movement in the UK. Law and Society Review 46(3):523-556. http://dx.doi.org/10.1111/ j.1540-5893.2012.00505.x

Victorian Environmental Water Holder. 2013. Reflections: environmental watering in Victoria 2012-13. State Government of Victoria, Melbourne, Australia.

Warnock, M. 2012. Should trees have standing? Journal of Human Rights and the Environment 3(Special Issue):56-67. http://dx.doi. org/10.4337/jhre.2012.02.03

Wheen, N., and J. Hayward. 2012. Treaty of Waitangi settlements. Bridget Williams Books, Wellington, New Zealand. http://dx.doi. org/10.7810/9781927131381 
Whittemore, M. E. 2011. The problem of enforcing nature's rights under Ecuador's constitution: why the 2008 environmental amendments have no bite. Pacific Rim Law and Policy Journal 20:659-691.

World Economic Forum. 2015. Global risks 2015. World Economic Forum, Geneva, Switzerland. 